\title{
慢性湿疹・皮膚炎群に対するヒスタグロビン 間歇適量療法の効果
}

\author{
九州大学医学部皮科教室（主任：占部治邦教授） \\ 中山樹一郎・松本忠彦・武石正昭 \\ 松田知子・今山修平・且崎治行 \\ 八島豊・占部治邦
}

慢性湿疹·皮潧炎群に対するヒスタグロピン 2 週に 1 回， 3 バイアル投与法の臨床効果を， Lーシステイン製荗を対照薬として検討した。

1) 解析対象例の内訳は, ヒスタグロビン (HG) 群 20 例, L-システイン製剤 (LC) 群 11 例であつた。

2） HG 群と LC 群の患者背景には，分布に差を認めなかつた。

3） HG 群の有効率は $90 \%$, LC 群の有効率は $45.5 \%$ で, HG 群が LC 群より優れてい た。有用性も同様の結果であつた。

4）ステロイド外用剂, 抗ヒスタミン剂使用量では, HG 群にステロイド外用剂の堿少傾 向が認められた。

5）臨床症状を初診時と比較すると, HG 群では疼痒, 紅斑, 丘疹, 苔解化, LC 群では

痖痒, 紅斑, 丘疹に有意な改善が見られた。

6）全般改善度は, HG 群が LC 群より優れていた。

7）副作用, 臨床検査異常値は認められなかつた。

\section{はじめに}

ヒスタタロビンは, ヒスタミン固定能の付与という概 念てその菜理作用が理解されてきだ。即時型アレル ギー抑制作用については21, in vitro で肥满細胞"，好塩 基球り用いた報告があり，興味深い。

アレルギー性皮涌疾患に対して現在数種のケミカルメ ディエーターの遊離抑制剂が，抗アレルギー刻として広 く使用されている゙作。これは原因療法に一步近づいた 治療ということができる。

近年開発された薬効および安全性の高い薬绪は、慢性 の皮唐疾患に対して長期の投薬を可能にした。それは， 患者の社会活動を円滑に行う上で役立つものとなつてい る。

今回, 慢性湿疹・皮甪炎群に対するヒスタグロビンの 有用性を検討する目的で,ヒスタグロビン 2 週間に 1 回，3バイアルの皮下注射を行つたので，その結果を報 告する。
方法

\section{1. 試験对象}

九州大学医学部附属病院たょび開連病院の皮科外来 を受診し, 慢性湿侩,アトピー皮炎炎, 脂漏性皮拥炎, 貨幣状湿疹, 急性湿疹（長期の経過を示すもの）と診断 された患者のうち, 慢性, 長期の経過を持つ症例を試験 対象とした。ただし，妊婦もしくは妊娠している可能性 のある婦人とステロイド凮の経口投与を行つている症例 は対象より除外した。

\section{2. 却駼萧郕}

ヒスタグロビン (HG)：1バイアル中, ヒト血清 $\gamma$-グロブリン $12 \mathrm{mg}$, ヒスタミン二塩酸塩 $0.15 \mu \mathrm{g}$ を 含有する。

L-システイン製戍 $(\mathrm{LC}) ： 1$ アンプル $(2 \mathrm{ml})$ 中, Lシステイン $0.1 \%$ を含有する。

\section{3. 恜験方法}

対象患者を封筒法でA，Bの 2 群に分けた。A群に は HG，B群には LCを投与した。HGは 1 回 3 バイア 
ルを $3 \mathrm{ml}$ の注射用蒸留水に溶解し, 2 週間に 1 回の皮 下注射を計 6 回投与することとした。また, LC は $2 \mathrm{ml}$ を $\mathrm{HG}$ と同一の間隔で計 6 回皮下注射で投与した。

\section{4. 併用薬郕}

ステロイド外用昘, 抗ヒスタミン剂を併用したが, 試 験期間中は原則として同一薬剤を使用することとした。 ステロイド外用剤は, 初めて受診した患者には strong または medium の薬効力を有するもの，すてにステロ イド外用剤を使用している患者にはそれまでの外用剤を 継続投与した。ただし, デルモベート, リンデロン DP は併用薬剤から除外した。抗ヒスタミン剂の使用は必要 最少量とし、ステロイドとの配合剤の使用は不可とし た。

また，試験期間中のステロイド外用剤，抗ヒスタミン 剤の使用量を各注射日に記録することとした。

その他, 試験薬都の㹝果判定に直接影響をおよばすと 考えられるものは用いないこととした。

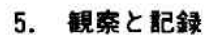

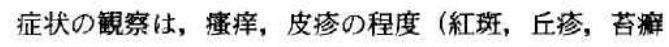
化),および各症状を総合した重症度について各注射日, および効果判定日（投与終了日より1〜2週間後）に行 い, 高度 (4), 中等度 (3), 軽度 (2), 軽微 (1), なし （0）の5段階（重症度スコア）で評価した。

\section{6. 全般改普度}

各注射日と第 1 回注射日の所見の比較により, 治癌 $(+1)$, 著明改善 $(+)$, 改善 $(+)$, 不変 $(0)$, 悪化 (×)の 5 段階で評価した。また, 改善以上をもつて改 善率を算定することとした。

\section{7. 副作用}

副作用が見られた場合は症状, 発生時期, 経過につい て詳細に記載することとした。

\section{8. 効果判定と緮合判定}

第 1 回注射日を基準として効果判定日までの全般改善 度, 重症度および併用薬剤の推移を総合し, 著効, 有 奻, 無奻, 悪化の 4 段階で臨床効果を評価した。また有 効以上をもつて有効率を算定した。

臨床效果と副作用を総合し, きわめて有用, 有用, 有 用性なしの 3 段階で有用性を評価した。また有用以上を もつて有用率を算定した。

\section{9. 一般監床検查}

投与前後の血液一般検查, 尿検査および血清 $\mathrm{IgE}$ 值, $\gamma$-グロプリン, グロプリン分画の測定を可能な症例に ついて行うこととした。

10. 解析 法

2 群の群間比較は Mann-Whitney のU検定, 名義尺
度のデー夕は $x^{2}$-検定, 対応のある順位デー夕は Wilcoxon-test, 計量值は student-T（II）を用いた。 有意水準は $\alpha=0.05$ とした。

\section{結果}

\section{1. 実施症例}

総症例数は 47 例, うち HG 群 26 例, LC 群 21 例て あつた。除外 4 例, 脱落 12 例, 計 16 例を解析対象から はずしたが，その構成には偏りはなかつた。脱落例のう ち LC群の 3 例は患者の希望で中止したものであつた。

したがつて, 解析対象は HG 群 20 例, LC 群 11 例で あつた(衰 1, 2)。

\section{2. 背最因子}

性別, 年令, 痽病期問, 疾患名, 重症度および投与回 数に、2 群間に分布の偏りはなかつた（部 3 )。

\section{3. 治境成繶}

1) 効果判定および有用性

有効率は HG 群 $90 \%(18 / 20)$, LC 群 $45.5 \%$ (5/ 11)で, HG 群が優れていた（表 4)。

また，有用性においても同様の成績が得られた 5 )。

2) ステロイド外用剤，抗ヒスタミン剂使用量の推移 投与開始時と投与終了時におけるステロイド外用剂, 抗ヒスタミン剂の薬剤使用量 ( 2 週間) を比較した（哀 $6)$ 。

HG 群は, ステロイド外用郕は $23.8 \%$, 抗七スタミ ン剂は $13.5 \%$ の減少を示した。ステロイト外用都は減 少の傾向を示した $(\mathrm{p}<0.10)$ 。LC群ては，ステロイド 外用郕は $13 \%$ 減少したが，抗七スタミン刺の使用量に

奉 1 赛施症例

\begin{tabular}{|c|c|c|c|c|}
\hline 症例の内訳 & HG 群 & LC 群 & 計 & 㭘定 $\left(\gamma^{2}\right)$ \\
\hline 投 与 例 & 26 & 21 & 47 & 次 \\
\hline $\begin{array}{l}\text { 除 外例 } \\
\text { 脱数 落 } \\
\text { 数 }\end{array}$ & $\begin{array}{r}2 \\
4 \\
20\end{array}$ & $\begin{array}{r}2 \\
8 \\
11\end{array}$ & $\begin{array}{r}4 \\
12 \\
31\end{array}$ & $3.453^{\text {N.s. }}$ \\
\hline
\end{tabular}

N.S. : 有意差なし, $\uparrow: p<0.1, \cdots: p<0.05, \cdots: p<0.01$

衰 2 除外, 脱落例の内訳

\begin{tabular}{|c|c|c|c|c|}
\hline \multicolumn{2}{|r|}{ 理 } & \multirow{2}{*}{\begin{tabular}{|c|}
$\mathrm{HG}$ 群 \\
1 \\
1 \\
0 \\
0
\end{tabular}} & \multirow{2}{*}{\begin{tabular}{|c|} 
LC 群 \\
0 \\
0 \\
1 \\
1
\end{tabular}} & \multirow[b]{2}{*}{$\begin{array}{c}\text { 計 }^{2} \\
1 \\
1 \\
1 \\
1\end{array}$} \\
\hline 外 & $\begin{array}{l}\text { デルモベート使用 } \\
\text { デルモ゙ートロ セレスタミン使用 } \\
\text { リンデロンDP, 七レスタミン使用 } \\
\text { 奻果判定不能 }\end{array}$ & & & \\
\hline \begin{tabular}{l|} 
脱 \\
落
\end{tabular} & $\begin{array}{l}\text { 来院せず (転勤) } \\
\text { 来院せす（理由不明） } \\
\text { 患者の希望 }\end{array}$ & $\begin{array}{l}1 \\
3 \\
0\end{array}$ & $\begin{array}{l}0 \\
5 \\
3\end{array}$ & $\begin{array}{l}1 \\
8 \\
3\end{array}$ \\
\hline & 計 & 6 & 10 & 16 \\
\hline
\end{tabular}


衰 3 解析対象例の背景因子

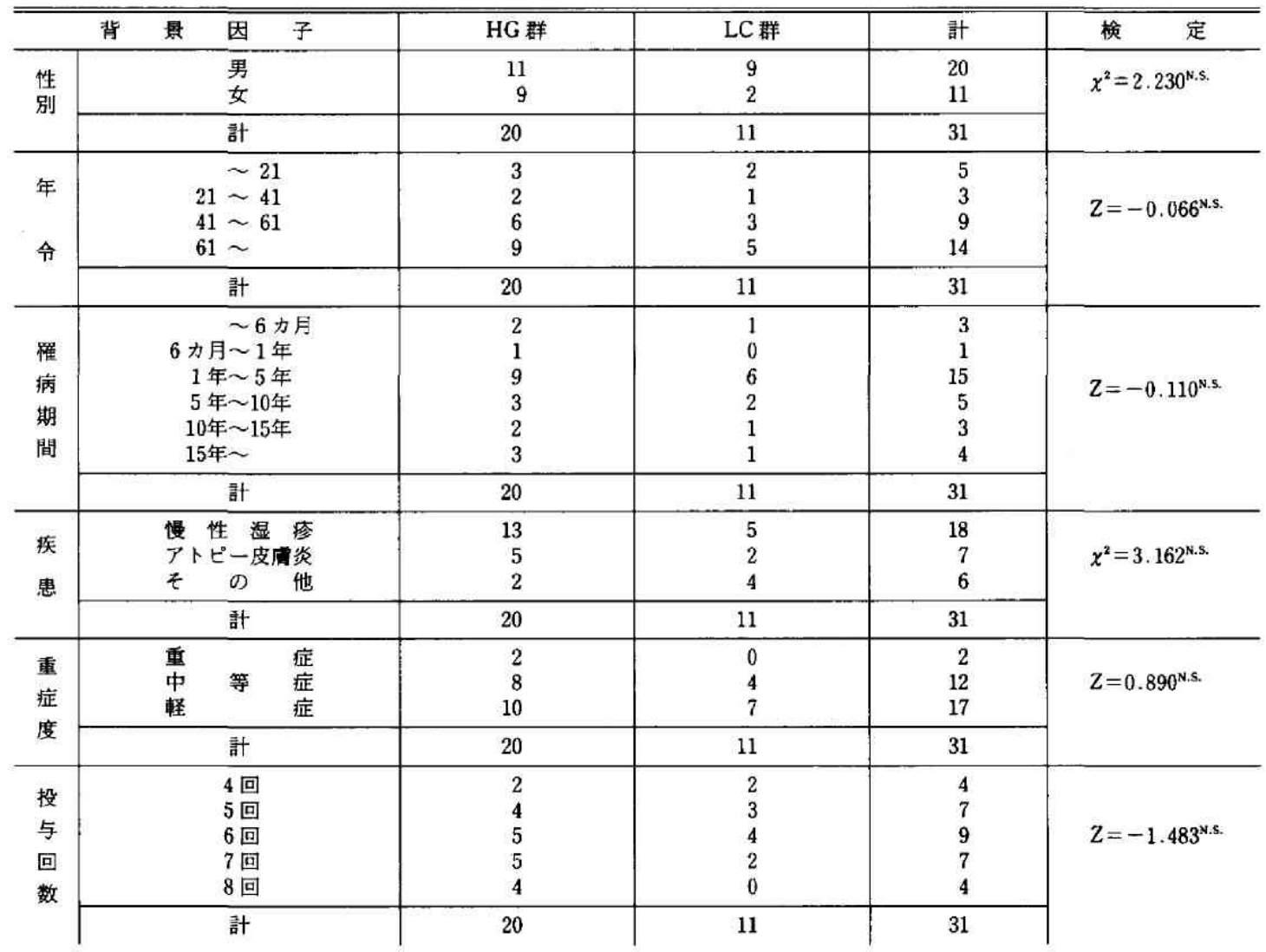

衰 4 奻 果判定

\begin{tabular}{c|c|c|c|c|c|c|cc}
\hline \hline 群 & 著 効 & 有 効 & 無 効 & 悪 化 & 計 & 有効率 (\%) & 娭 & 定 (Uo) \\
\hline HG 群 & 5 & 13 & 2 & 0 & 20 & 90.0 & \multirow{2}{*}{$2.406^{*}$} \\
LC 群 & 1 & 4 & 6 & 0 & 11 & 45.5 &
\end{tabular}

5 有表 5 性

\begin{tabular}{|c|c|c|c|c|c|c|}
\hline 群 & きわめて有用 & 有 & 有用性なし & 計 & 有用率 $(\%)$ & 娭 定 (Uo) \\
\hline HG 群 & 5 & 13 & 2 & 20 & 90.0 & \multirow{2}{*}{$2.406^{\circ}$} \\
\hline LC 群 & 1 & 4 & 6 & 11 & 45.5 & \\
\hline
\end{tabular}

変化はなかつた。

3）臨床症状と重症度の推移

最終観察日において, HG 群では瘦痒, 紅斑, 丘疹,

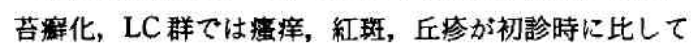
有意に改善した。

重症度も同様の結果であつた（事 7)。

4) 全般改善度の推移
HG 群では, 1 回注射後の判定 (2 回目注射時)て $50 \%$, 以後 $70,85,100 \%$ と改善した。LC群ではそれ ぞれ36，64，64，83\%の改善率であつた。また, HG 群の改善率は 4 回注射後の判定 ( 5 回目注射時) 後, 一 定に達した（率8)。

全般改善度は，HG 群がLC群より優れていた 9)。 
表 6 ステロイド外用剤, 抗ヒスタミン剂使用量の推移

\begin{tabular}{|c|c|c|c|c|c|}
\hline \multirow{2}{*}{ 䒴 } & \multirow{2}{*}{$\begin{array}{lll} & \text { 群 } & \\
\text { (症 例 数) }\end{array}$} & \multicolumn{2}{|c|}{ 薬剂使用量：mean \pm S. D. ( 2 週間) } & \multirow{2}{*}{ 差 $(a-b)$} & \multirow{2}{*}{ 検 定 (to) } \\
\hline & & 投与開始時 & 投与終了時 & & \\
\hline \multirow{2}{*}{$\begin{array}{r}x \\
\bar{\tau} \\
\text { 外口 } \\
\text { 角 } \\
\text { 教 } \\
\end{array}$} & $\begin{array}{l}\text { HG 群 } \\
\text { (20例) }\end{array}$ & $26.8 \pm 26.5 \mathrm{~g}$ & $20.4 \pm 29.1 \mathrm{~g}$ & $6.4 \pm 14.8 \mathrm{~g}$ & $1.920^{\top}$ \\
\hline & $\begin{array}{l}\text { LC 群 } \\
\text { (11例) }\end{array}$ & $33.2 \pm 42.2 \mathrm{~g}$ & $28.9 \pm 33.4 \mathrm{~g}$ & $4.3 \pm 12.9 \mathrm{~g}$ & $1.106^{\mathrm{NSS} .}$ \\
\hline \multirow{2}{*}{$\begin{array}{l}\text { 热 } \\
\text { 至 } \\
\text { 多 } \\
\text { 三 } \\
\text { 剂 }\end{array}$} & $\begin{array}{l}\text { HG 群 } \\
\text { (20例) }\end{array}$ & $36.3 \pm 23.9 \mathrm{~T}$ & $31.4 \pm 19.4 \mathrm{~T}$ & $4.9 \pm 16.5 \mathrm{~T}$ & $1.324^{\text {N.S. }}$ \\
\hline & $\begin{array}{l}\text { LC 群 } \\
\text { (11例) }\end{array}$ & $25.5+19.6 \mathrm{~T}$ & $25.5+19.6 \mathrm{~T}$ & 0 & - \\
\hline
\end{tabular}

HG 群（演接)

\begin{tabular}{|l|c|c|c|c|c|c|}
\hline $1 \backslash 2$ & 高 度 & 中等度 & 軽 度 & 軽 微 & な & 計 \\
\hline 高 度 & 0 & 1 & 0 & 0 & 1 & 2 \\
\hline 中等度 & 0 & 0 & 4 & 6 & 5 & 15 \\
\hline 軽 度 & 0 & 0 & 1 & 1 & 1 & 3 \\
\hline 軽 微 & 0 & 0 & 0 & 0 & 0 & 0 \\
\hline な し & 0 & 0 & 0 & 0 & 0 & 0 \\
\hline 計 & 0 & 1 & 5 & 7 & 7 & 20 \\
\hline
\end{tabular}

1 : 第 1 回注射日, 2 : 最終箸察日（以下同様）

HG 群(紅斑)

\begin{tabular}{|c|c|c|c|c|c|c|}
\hline $1 \backslash 2$ & 高 度 & 中等度 & 軽 度 & 軽 微 & な & 計 \\
\hline 高 度 & 0 & 0 & 0 & 0 & 0 & 0 \\
\hline 中等度 & 0 & 0 & 3 & 2 & 1 & 6 \\
\hline 軽 度 & 0 & 0 & 1 & 4 & 2 & 7 \\
\hline 軽 微 & 0 & 0 & 0 & 2 & 3 & 5 \\
\hline な し & 0 & 0 & 0 & 0 & 2 & 2 \\
\hline 計 & 0 & 0 & 4 & 8 & 8 & 20 \\
\hline
\end{tabular}

HG 群 (丘疹)

\begin{tabular}{|l|c|c|c|c|c|c|}
\hline $1 \backslash 2$ & 高 度 & 中等度 & 軽 度 & 軽 微 & な し & 計 \\
\hline 高 度 & 0 & 0 & 2 & 1 & 1 & 4 \\
\hline 中等度 & 0 & 0 & 4 & 2 & 0 & 6 \\
\hline 軽 度 & 0 & 0 & 0 & 3 & 3 & 6 \\
\hline 軽 微 & 0 & 0 & 0 & 0 & 1 & 1 \\
\hline な し & 0 & 0 & 0 & 0 & 3 & 3 \\
\hline 計 & 0 & 0 & 6 & 6 & 8 & 20 \\
\hline Wilcoxon (I): Uo & \multicolumn{7}{|c|}{$3.670^{* *}$} \\
\hline
\end{tabular}

LC 群 (位㭔)

\begin{tabular}{|l|c|c|c|c|c|c|}
\hline $1 \backslash 2$ & 高 度 & 中等度 & 軽 度 & 軽 微 & な & 計 \\
\hline 高 度 & 0 & 1 & 0 & 0 & 0 & 1 \\
\hline 中等度 & 0 & 2 & 0 & 2 & 1 & 5 \\
\hline 軽 度 & 0 & 0 & 1 & 2 & 1 & 4 \\
\hline 軽 徽 & 0 & 0 & 0 & 1 & 0 & 1 \\
\hline な し & 0 & 0 & 0 & 0 & 0 & 0 \\
\hline 計 & 0 & 3 & 1 & 5 & 2 & 11 \\
\hline
\end{tabular}

LC 群（紅斑）

\begin{tabular}{|l|c|c|c|c|c|c|}
\hline $1 \backslash 2$ & 高 度 & 中等度 & 軽 度 & 軽 微 & な & 計 \\
\hline 高 度 & 0 & 0 & 0 & 0 & 0 & 0 \\
\hline 中等度 & 0 & 2 & 2 & 2 & 1 & 7 \\
\hline 軽 度 & 0 & 0 & 1 & 2 & 0 & 3 \\
\hline 軽 徽 & 0 & 0 & 0 & 1 & 0 & 1 \\
\hline な し & 0 & 0 & 0 & 0 & 0 & 0 \\
\hline 計 & 0 & 2 & 3 & 5 & 1 & 11 \\
\hline \multicolumn{6}{|c|}{ Wilcoxon (I): Uo } \\
\hline
\end{tabular}

LC 群 (丘疹)

\begin{tabular}{|l|c|c|c|c|c|c|}
\hline $1 \backslash 2$ & 高 度 & 中等度 & 軽 度 & 軽 微 & な し & 話 \\
\hline 高 度 & 0 & 0 & 0 & 0 & 0 & 0 \\
\hline 中等度 & 0 & 1 & 1 & 1 & 1 & 4 \\
\hline 軽 度 & 0 & 0 & 1 & 2 & 0 & 3 \\
\hline 軽 微 & 0 & 0 & 0 & 0 & 1 & 1 \\
\hline な し & 0 & 0 & 0 & 0 & 3 & 3 \\
\hline 計 & 0 & 1 & 2 & 3 & 5 & 11 \\
\hline Wilcoxon (I): Uo & \multicolumn{7}{|c|}{$2.157^{*}$} \\
\hline
\end{tabular}


HG 群 (苔冓化)

\begin{tabular}{|c|c|c|c|c|c|c|}
\hline $1 \backslash 2$ & 高 度 & 中等度 & 軽 度 & 軽 微 & な し & 計 \\
\hline 高 度 & 0 & 0 & 0 & 1 & 1 & 2 \\
\hline 中等度 & 0 & 0 & 4 & 1 & 1 & 6 \\
\hline 軽 度 & 0 & 0 & 1 & 4 & 3 & 8 \\
\hline 軽 微 & 0 & 0 & 0 & 0 & 0 & 0 \\
\hline な L & 0 & 0 & 0 & 0 & 4 & 4 \\
\hline 計 & 0 & 0 & 5 & 6 & 9 & 20 \\
\hline \multicolumn{7}{|c|}{ Wilcoxon (I): Uo } \\
\hline
\end{tabular}

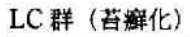

\begin{tabular}{|l|c|c|c|c|c|c|}
\hline $1 \backslash 2$ & 高 度 & 中等度 & 軽 度 & 軽 微 & な し & 計 \\
\hline 高 度 & 0 & 0 & 0 & 0 & 0 & 0 \\
\hline 中等度 & 0 & 0 & 0 & 1 & 0 & 1 \\
\hline 軽 度 & 0 & 0 & 2 & 3 & 1 & 6 \\
\hline 軽 微 & 0 & 0 & 0 & 0 & 0 & 0 \\
\hline な し & 0 & 0 & 0 & 0 & 4 & 4 \\
\hline 計 & 0 & 0 & 2 & 4 & 5 & 11 \\
\hline \multicolumn{7}{|c|}{ Wilcoxon (I): Uo } \\
\hline \multicolumn{7}{|l|}{} \\
\hline
\end{tabular}

HG 群 (重症度)

\begin{tabular}{|c|c|c|c|c|c|c|}
\hline 1 \2 & 高 度 & 中等度 & 軽 度 & 軽 微 & な し & 計 \\
\hline 高 度 & 0 & 1 & 0 & 1 & 0 & 2 \\
\hline 中等度 & 0 & 0 & 3 & 5 & 0 & 8 \\
\hline 軽 度 & 0 & 0 & 2 & 5 & 3 & 10 \\
\hline 軽 微 & 0 & 0 & 0 & 0 & 0 & 0 \\
\hline な し & 0 & 0 & 0 & 0 & 0 & 0 \\
\hline 計 & 0 & 1 & 5 & 11 & 3 & 20 \\
\hline Wilcoxon (I): Uo & \multicolumn{7}{|c|}{$395^{* *}$} \\
\hline
\end{tabular}

\section{LC 群（重症度）}

\begin{tabular}{|c|c|c|c|c|c|c|}
\hline $1 \backslash 2$ & 高 度 & 中等度 & 軽 度 & 軽 微 & な & 計 \\
\hline 高 度 & 0 & 0 & 0 & 0 & 0 & 0 \\
\hline 中等度 & 0 & 0 & 3 & 1 & 0 & 4 \\
\hline 軽 度 & 0 & 0 & 4 & 3 & 0 & 7 \\
\hline 軽 徽 & 0 & 0 & 0 & 0 & 0 & 0 \\
\hline な し & 0 & 0 & 0 & 0 & 0 & 0 \\
\hline 計 & 0 & 0 & 7 & 4 & 0 & 11 \\
\hline \multicolumn{7}{|c|}{ Wilcoxon (I): Uo } \\
\hline
\end{tabular}

衰 8 全般改善度の推移

\begin{tabular}{|c|c|c|c|c|c|c|c|c|c|}
\hline \multirow{2}{*}{ 注射回数 } & \multirow{2}{*}{ 群 } & \multicolumn{3}{|c|}{ 全 般 } & 改 & \multicolumn{2}{|l|}{ 度 } & \multirow{2}{*}{ 計 } & \multirow{2}{*}{ 改善率 (\%) } \\
\hline & & 治 & 著明改善 & 改 & 善 & 不 変 & 覀 化 & & \\
\hline \multirow{2}{*}{2 回目 } & HG 群 & 0 & 4 & & 6 & 10 & 0 & 20 & 50.00 \\
\hline & LC 群 & 0 & 0 & & 4 & 7 & 0 & 11 & 36.36 \\
\hline \multirow{2}{*}{3 回目 } & HG 群 & 0 & 6 & & 8 & 5 & 1 & 20 & 70.00 \\
\hline & LC 群 & 0 & 1 & & 6 & 2 & 2 & 11 & 63.64 \\
\hline \multirow{2}{*}{4 回目 } & HG 群 & 2 & 6 & & 9 & 3 & 0 & 20 & 85.00 \\
\hline & LC 群 & 1 & 2 & & 4 & 4 & 0 & 11 & 63.64 \\
\hline \multirow{2}{*}{5 回日 } & HG 群 & 4 & 9 & & 5 & 0 & 0 & 18 & 100.00 \\
\hline & LC 群 & 0 & 3 & & 3 & 3 & 0 & 9 & 66.67 \\
\hline \multirow{2}{*}{6 回目 } & HG 群 & 3 & 7 & & 4 & 0 & 0 & 14 & 100.00 \\
\hline & LC 群 & 0 & 2 & & 3 & 1 & 0 & 6 & 83.33 \\
\hline \multirow{2}{*}{7 [回目 } & HG 群 & 2 & 5 & & 2 & 0 & 0 & 9 & 100.00 \\
\hline & LC 群 & 0 & 0 & & 2 & 0 & 0 & 2 & - \\
\hline \multirow{2}{*}{8 回目 } & HG 群 & 1 & 1 & & 2 & 0 & 0 & 4 & - \\
\hline & LC 群 & 0 & 0 & & 0 & 0 & 0 & 0 & - \\
\hline
\end{tabular}

衰 9 全般改善度

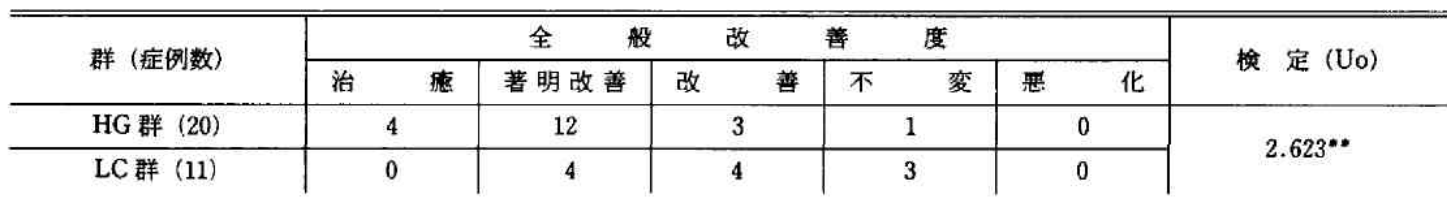




\section{4. 副作用および一般臨床検查}

2 群とも特記すべき副作用は認められず，一般臨床検 査成績もすべて正常範囲内であつた。また，投与前後の 血清 $\mathrm{gEE}$ 值, $\gamma$-ダロブリン值, グロブリン分画に変動 は認めなかつた。

\section{かんが え}

HG は，アレルギー疾患患者に減弱ないし消失してい るヒスタミン固定能を付与する製郕として使用され，す でに 20 余年がたつ。この間，皮唐科領域においても二 重盲検法によるアレルギー性皮溥疾患に対する治療効 果”や，1回投与量の再検討などの報告がみられ $3^{\text {(3) } \sim 12)}$ 。

今回，われわれは慢性，長期の経過をもつ慢性湿疹・ 皮唐炎群に HG 2 週間に 1 回，3バイアル投与する方 法てその臨床効果を検討した。

コントロールとして LCを用いたが，患者を封筒法に よつて振り分けたため, 二重盲検法ほどの繁密な比較検 討は不可能であつた。少なくとも，対象患者の背景因子 には HG 群と LC 群の間に偏りはなかつた。

臨床効果, 有用性については, HG 群が LC 群に比較 して優れていた。また，ステロイド外用剤の使用量は HG 群に隇少傾向が認められた。臨床症状の推移では, 苦絴化において HG 群が優れていた。また，全般改善 度も同様であり，その改善率は 4 回注射後より一定に達 した。

以上の結果より, HG は 2 週間に 1 回 3 バイアル，4 回投与で有効であると考えられた。

投与前後の $r$ グロプリン值, グロブリン分画に変動 はみられなかつた。

この結果は，HG が抗ヒスタミン抗原として作用する という仮説からは説明が困難である。むしろ最近のヒト

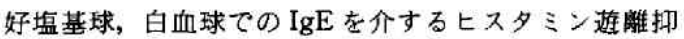
制作用が機序としては有力と思われる。このヒスタミン 遊排排作用は HG 中のヒスタミンが好塩基球の $\mathrm{H}_{2}$-receptor と結合し，ヒスタミン遊離を抑制的に制御 するためといわれ，その際 $\gamma$ グロブリンも Fc-receptor を介して好塩基球に作用するらしい。

2 週間に 1 回， 3 バイアルの $\mathrm{HG}$ 投与が有効である 理由は,つぎのように推測される。

(1) HGに含まれる $\gamma$ グロブリンの肥満細胞, 好塩 基球との非特異的あるいは特異的な結合反㐫が，かなり 長期にわたる。
（2）一度結合反応が成立すると，紏胞内の七スタミン 遊離機構が何らかの理由で長期におさえられる。

HG 4 回投与後, その奻果が一定に達したことの説明 としては, HG のヒスタミン遊離の長期打制効果のほか に抗ヒスタミン抗体の産生も完全には否定できない。

湿疹・皮成炎群の各病型ごとの有効性を检討するには, さらに多数の解析症例を要し, 今後の検討課題である。

\section{文献}

1）上スタダロビン文献集，日本缄器製菜株式会社，1971.

2) 谷崎勝朗ほ加: Histamin-gammagloblin conjugate の即時型アレルギー反応に対する抑制作用. 臨牒と研究 61:3382, 1984 .

3) Ishikawa $T$ et al: Inhibition of rat mast cell degranulation and histamin release by histamin-rat gam. maglobulin conjugate. Int Arch Allergy Appl Immunol $59: 403,1979$

4）大西章元ほか：ヒスタミン加ヒト $\gamma$ グロブリンのヒト 白血球からのヒスタミン遊離抑制。政床免疫 $17: 1145$, 1985.

5) Koda $\mathrm{A}$ et al : Inhibition of hyper sensitivity reaction by a new drung; $\mathrm{N}\left(3^{\prime}, 4^{\prime}\right.$-dimethoxy-cinnamoyl) anthranilic acid $\left(\mathrm{N}-5^{\prime}\right)$. J Aller Clin Immunol 57 : 396, 1976.

6) Tomita $\mathrm{H}$ et al: Inhibition of chemical mediator release from human leukocyte by a new antiasthma drug. HC20-511 (Ketotifen). Monographs in Allergy 14: 313,1979 .

7）ヒスタグロビン研究班：二重盲梌法によるヒスタグロ

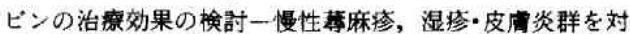
象として一。西日皮涄 $42: 470 ， 1980$.

8）松本忠彦ほか：ヒスタクロビンの大量粕法。西日皮用 $36: 576,1974$.

9）山口全一ほか：惯性蓒麻疹に対する Histaglobin 㙩法 についてーとくに1回投与量の增鼻に関する検討を中心 として一. 治療 62: 1033, 1980 。

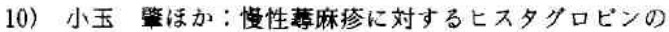
治療効果一 2 バイアル投与法に上る检討一，基礎上臨床 $14: 156,1980$.

11）喜多野征夫活加：湿疹・皮阅炎群に対するヒスタグロビ ン大量撩法の有効性の検討. 基礎と臨床 $14: 1317$, 1980.

12）安野洋一涹か：ヒスタダロビンによる湿疮・皮闻炎群の

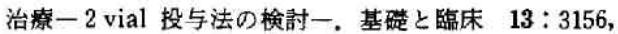
1980.

(昭和 61 年 6 月 24 日 受付・特揭)

別刷請求先： $\mathbf{T} 812$ 福岡市東区馬出 3-1-1 九州大学医学部皮科教室 中山 樹一郎 